\title{
Findings of the Signal Approach for Financial Monitoring in Kazakhstan
}

\author{
Klaus Abberger \\ Wolfgang Nierhaus \\ Shynar Shaikh
}

\author{
CESIFO WORKING PAPER No. 2774 \\ CATEGORY 12: EMPIRICAL AND THEORETICAL METHODS \\ SEPTEMBER 2009
}

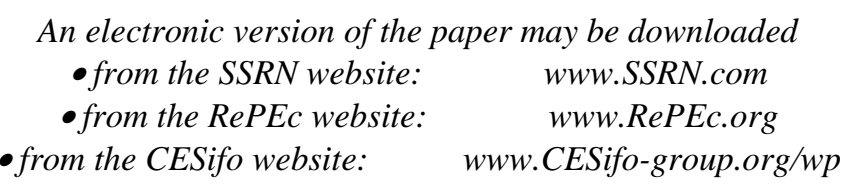




\title{
Findings of the Signal Approach for Financial Monitoring in Kazakhstan
}

\begin{abstract}
This study concentrates on the signal approach for Kazakhstan. It focuses on the properties of individual indicators prior to observed currency crises. The indicators are used to build composite indicators. An advanced approach uses principal components analysis for the construction of composite indicators. Furthermore, the common signal approach is improved by robust statistical methods. The estimation period reaches from 1997 to 2007. It is shown that most of the composite indicators are able to flag the reported crises at an early stage. In a second step it is checked whether the most recent crisis in 2009 is signalled in advance.
\end{abstract}

JEL Code: E32, E37, E59.

Keywords: currency crises, leading economic indicators, signal approach, Kazakhstan.

Klaus Abberger
Ifo Institute for Economic Research at the University of Munich
Poschingerstrasse 5
Germany - 81679 Munich
Abberger@ifo.de
Wolfgang Nierhaus

The Paper was produced in the context of an Early Warning Project conducted in collaboration with the National Analytical Centre of the Government and the National Bank of the Republic of Kazakhstan which has been supported by the German VW Foundation. 
Forecasting currency crises is a challenging task. A well-known standard approach is the signal approach developed by Kaminsky, Lizondo and Reinhart (KLR). ${ }^{1}$ Following this approach currency crises are identified by means of a foreign exchange market pressure index. This pressure index serves as a reference series for dating currency crises. In a second step KLR propose the monitoring of macroeconomic variables (single indicators) that may tend to show unusual behaviour in periods (one or two years) prior to currency turbulences. An indicator sends a crisis warning signal whenever it moves beyond a given critical threshold. Moreover, composite indicators can be constructed that encompass the signalling behaviour of the selected individual indicators. Finally, crises probabilities can be estimated. This procedure, which can be performed for each single country with reported currency crises, characterizes the signal approach.

From the statistical point of view the signal approach can be characterized as a nonparametric approach, since it does not require the assumption of a specific model (in contrast to logit models or Markov regime-switching models). Indeed the parametric models may be more efficient, when the models assumptions hold in reality. The signal approach on the other hand should be a quite versatile method. It should be especially advantageous when data quality is quite unsure and/or when dependencies between macroeconomic variables might not be stable. Dependencies could be time varying in developed countries, but this problem should be of especial importance in developing countries like Kazakhstan. In such cases the signal approach will be a rather robust method for monitoring currency crises. So, even when there are model based approaches working well within available samples, the signal approach has its own justification because it is a nonparametric method. In this study the signal approach is refined by outlier robust estimation methods, which further enhances the usefulness of the signal approach.

The following empirical study concentrates on the signal approach for Kazakhstan. It focuses on the signalling properties of several individual macroeconomic indicators prior to episodes of foreign exchange market turbulences in Kazakhstan, as indicated by

\footnotetext{
1 See Kaminsky, Lizondo, Reinhart (1998),
} 
the exchange market pressure index. The individual indicators are used to build composite currency crises indicators by exploiting the signal behaviour of each individual indicator. A more advanced approach uses principal components analysis of the individual indicators to construct composite indicators. The estimation period of the critical thresholds reaches from January 1997 to December 2007. For this time span it is shown that most of the composite indicators are able to flag the two reported currency crises in this time span at an early stage (in-sample analysis). In a second step it is checked whether the most recent crisis in February 2009 is signalled by the composite indicators in advance (out-of-sample analysis). In an annex, the model based parametric Markov regime-switching approach is briefly discussed ${ }^{1}$. All data was taken from the Agency of Statistics of the Republic of Kazakhstan, the National Bank of Kazakhstan and International Financial Statistics (IFS), published by the International Monetary Fond.

An important requirement for an early-warning system to function properly is timeliness. For this reason this study is based on monthly data or on quarterly data, which has been transformed into monthly data by means of temporal disaggregation techniques.

1 The econometric appoach can be also based on panel data of a group of countries with observed currency crises. The disadvantage of the panel approach is that country specifics might be neglected (e.g. for the case of Kazakhstan the predominant importance of oil prices). See Knedlik, Scheufele (2007). Berg, Pattillo (1999), Abiad (2003). 


\section{The Signal Approach \\ 1.1 Defining Currency Turbulences}

Following the signal approach, currency turbulences should be defined using definite criteria. Currency crises are identified by means of a foreign exchange market pressure index relying on the known symptoms of such episodes of currency turbulences: ${ }^{1}$

- a sudden and sharp devaluation of a currency,

- a substantial decrease in foreign exchange reserves

It is quite important to focus on both aspects, because currency crises can break out that leads to a sharp devaluation of a currency. But sometimes monetary institutions try to avoid these devaluations. They intervene to avoid or soften the devaluation. Although no sharp devaluation occurred in these cases, they are also currency crises because the authorities were forced to intervene. Such hidden or sometimes avoided crises are visible in the foreign exchange reserves because they are used to intervene. For a method, that is used to give early warnings on currency crises it is important that visible and hidden or avoided crises are included in the calculations. Hence an index of pressure in the foreign exchange market $\mathrm{IP}_{\mathrm{t}}$ at month $\mathrm{t}$ is constructed by using the monthly rates of change of the foreign exchange reserves and the real exchange rate.

$\mathrm{IP}_{\mathrm{t}}=\gamma_{1} \Delta \mathrm{wr}_{\mathrm{t}}-\gamma_{2} \Delta \mathrm{rer}_{\mathrm{t}}$

$\Delta w r_{t}$ is the monthly rate of change of the foreign exchange reserves; $\Delta \operatorname{rer}_{t}$ is the monthly rate of change of the real exchange rate, which is given by the nominal exchange rate of the Tenge to the USD, adjusted for the trends in consumer prices in the United States and in Kazakhstan. ${ }^{2}$ A rise in the real exchange rate corresponds to a real depreciation

1 See Kaminsky, Lizondo, Reinhart. (1998), Schnatz (1998, 1999a, 1999b), Deutsche Bundesbank (1999) and Nierhaus (2000).

2 The real exchange rate $\operatorname{rer}_{\mathrm{t}}$ is given by $\operatorname{rer}_{\mathrm{t}}=\mathrm{er}_{\mathrm{CURRENCY} \mid \mathrm{US} \$, \mathrm{t}} \bullet \mathrm{CPI}_{\mathrm{US}, \mathrm{t}} / \mathrm{CPI}_{\mathrm{t}}$. It follows that $\Delta \mathrm{rer}_{\mathrm{t}, \mathrm{t}} \approx \Delta \mathrm{er}-$ CURRENCY|US\$,t $+\Delta \mathrm{CPI}_{\mathrm{US}, \mathrm{t}}-\Delta \mathrm{CPI}_{\mathrm{t}}$. A real depreciation of the currency follows from a nominal depreciation of the currency and/or a rise in US consumer prices and/or a decline in domestic consumer prices. 
of the currency. Since the variances of $\Delta \mathrm{rer}_{, t}$ and $\Delta \mathrm{wr}_{\mathrm{t}}$ are different, they are weighted $\left(\gamma_{1}\right.$ and $\left.\gamma_{2}\right)$ by using the standard deviation of the variables. ${ }^{1}$ The real exchange rate is used to avoid corrections for periods with high inflation differentials between home and abroad. $^{2}$

Tensions in the foreign exchange market are identified for periods when the foreign exchange market index swings deeply into the negative. In the present study, for a currency turbulence, the pressure index $\mathrm{IP}_{\mathrm{t}}$ must exceed its mean $\mu$ more than 3 times the standard deviation $\sigma=\sqrt{ }_{\text {varIP }}{ }_{\mathrm{t}}{ }^{3}$ The parameters $\mu$ and $\sigma$ are unknown theoretical values, depending on the underlying distribution of $\mathrm{IP}_{\mathrm{t}}$.

Definition: month $\mathrm{t}$ with crisis event $<\Rightarrow \mathrm{IP}_{\mathrm{t}}<\mu-3 \sigma$

From that point, a window of three quarters is drawn. If a new event occurs in this area, then the time in-between is defined as a crisis episode. Otherwise the last point in time of the event is fixed as the end of the episode.

In a normal distribution the probability for an observation smaller than $\mu-3 \sigma$ would be about $0.135 \%$. So currency crises are very rare events, as they should be. Calculating respective probabilities from a distribution with heavy tails or an asymmetric distribution would indeed lead to larger values.

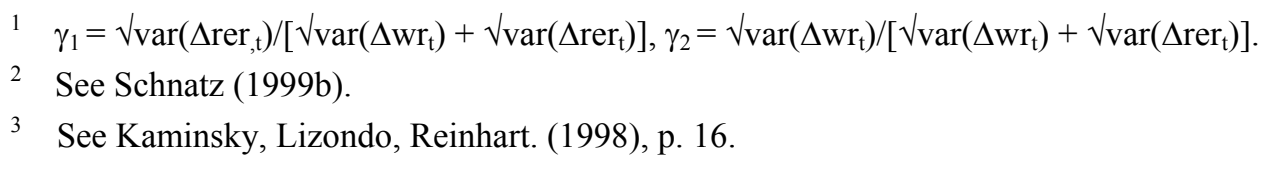


The true $\sigma$ is unknown and must be estimated from data at hand. ${ }^{1}$ Since the analysis of currency crises means searching for extreme events in time series, the question arises as to how to measure scale. Empirical variance and empirical standard deviation are estimators, which are very sensitive against outliers. Data used for the analysis of currency crises contain extreme events or outliers, therefore robust estimation methods might be preferable. With non-robust estimators, outliers could mask themselves. One robust measure of scale is the median of absolute deviations from the median (MAD). This robust scale estimator is used in the study at hand. The MAD is adjusted by a factor for asymptotically normal consistency. It holds

$$
E\left[1.4826 \bullet M A D\left(X_{1}, X_{2}, X_{3}, \ldots\right)\right]=\sigma
$$

for $X_{j}, j=1,2,3, \ldots, n$, distributed as $N\left(\mu, \sigma^{2}\right)$ and large $n$.

\subsection{Selecting Indicators}

The signal approach uses indicators to detect currency crises in advance. Since currency crises are extreme events, they usually are preceded by extreme developments or imbalances. So they might be detected by leading indicators, showing exceptional values before the crises starts. With this conception in mind it is obvious to condense the information contained in leading indicators to a binary variable, which differentiates whether the indicator is in a normal or in a extreme range. This is an important feature of the signal approach. The indicators are transformed to binary variables and are not used in there original form

From the statistical point of view the signal approach can be characterized as a nonparametric approach, since it does not require the assumption of a specific model (in contrast to logit models or Markov-switching models). Indeed the parametric models

\footnotetext{
1 Also unknown in $\mu$, which is estimated by the arithmetic mean $\mathrm{m}$ of $\mathrm{IP}_{\mathrm{t}}$.
} 
may be more efficient when the models assumptions hold in reality. The signal approach on the other hand should be a quite versatile method.

The signal approach proposes the monitoring of a quantity of macroeconomic variables (indicators) that may tend to show unusual patterns in periods prior to currency turbulences. Under the signal approach, a reasonable crises indicator should be systematically higher (or lower) prior to currency turbulences than in tranquil periods. Formally, an indicator is said to issue a warning signal if it exceeds (is below) a critical threshold level. This level has to be chosen appropriately to balance the risks of having numerous false signals and the risk of not registering crises. ${ }^{1}$ For all calculations a 12 -month crisis window is used.

To fix ideas, let $\mathrm{S}_{\mathrm{t}}$ be a binary signal variable, depending on the value of the individual indicator $\mathrm{V}_{\mathrm{t}}$ at time $\mathrm{t}$, the critical cutoff value $\delta$ and the expected sign (+/-) before crises:

$$
\mathrm{S}_{\mathrm{t}}^{+}=\left\{\begin{array}{ll}
1 & \text { if } \mathrm{V}_{\mathrm{t}}>\delta \\
0 & \text { if } \mathrm{V}_{\mathrm{t}} \leq \delta
\end{array} \quad \text { or } \mathrm{S}_{\mathrm{t}}^{-}= \begin{cases}1 & \text { if } \mathrm{V}_{\mathrm{t}}<\delta \\
0 & \text { if } \mathrm{V}_{\mathrm{t}} \geq \delta\end{cases}\right.
$$

In this concept the informative content of an observation at time $t$ is reduced to one of two possibilities: either the indicator exceeds (is below) the threshold $\delta$ and gives a crisis warning signal $\left(\mathrm{S}_{\mathrm{t}}=1\right)$, or it is below (exceeds) the threshold sending no signal $\left(\mathrm{S}_{\mathrm{t}}=0\right)$. However, there may be correct signals and false signals. An indicator sends a correct signal if

- $\mathrm{S}_{\mathrm{t}}=1$ and a crisis happens within 12 months

- $\mathrm{S}_{\mathrm{t}}=0$ and no crisis happens within 12 months.

1 See Kaminsky, Lizondo, Reinhart (1998). 
In the first case the indicator sends a signal and is followed within 12 months by a currency crisis. In the second case the indicator does not send a signal and is not followed by a crisis. By contrast, the indicator issues a false signal if

- $\mathrm{S}_{\mathrm{t}}=1$ and no crisis happens within 12 months

- $\mathrm{S}_{\mathrm{t}}=0$ and a crisis happens within 12 months.

In the third case the indicator sends a signal and is not followed by a crisis. In the last case the indicator does not send a signal and is followed by currency turbulence. Altogether, the performance of an indicator can be measured in terms of Table 1 .

Table 1

Classification Table

\begin{tabular}{|l|c|c|c|}
\hline Classification Table & $\begin{array}{c}\text { Crisis within } \\
\mathbf{1 2} \text { months }\end{array}$ & $\begin{array}{c}\text { No crisis within } \\
\mathbf{1 2} \text { months }\end{array}$ & Total \\
\hline Signal is sent: $\mathbf{S}_{\mathbf{t}}=\mathbf{1}$ & $\mathrm{A}$ (= number of signals) & $\mathrm{B}$ (= number of signals) & $\mathrm{A}+\mathrm{B}$ \\
\hline No signal is sent: $\mathbf{S}_{\mathbf{t}}=\mathbf{0}$ & $\mathrm{C}$ (= number of signals) & $\mathrm{D}$ (= number of signals) & $\mathrm{C}+\mathrm{D}$ \\
\hline Total & $\mathrm{A}+\mathrm{C}$ & $\mathrm{B}+\mathrm{D}$ & $\mathrm{A}+\mathrm{B}+\mathrm{C}+\mathrm{D}$ \\
\hline Correct & $\mathrm{A}$ & $\mathrm{D}$ & $\mathrm{A}+\mathrm{D}$ \\
\hline Correct as \% of total & $\mathrm{A} /(\mathrm{A}+\mathrm{C})$ & $\mathrm{D} /(\mathrm{B}+\mathrm{D})$ & $(\mathrm{A}+\mathrm{D}) /(\mathrm{A}+\mathrm{B}+\mathrm{C}+\mathrm{D})$ \\
\hline Incorrect as \% of total & $\mathrm{C} /(\mathrm{A}+\mathrm{C})$ & $\mathrm{B} /(\mathrm{B}+\mathrm{D})$ & $(\mathrm{B}+\mathrm{C}) /(\mathrm{A}+\mathrm{B}+\mathrm{C}+\mathrm{D})$ \\
\hline
\end{tabular}

Following KLR, a perfect indicator would only produce signals that belong to the northwest and south-east cells of the inner matrix (see shadowed area). It would issue a signal in every month that is followed by a crisis $(\mathrm{A}>0)$, so that the number of missing warning signals $\mathrm{C}$ equals zero, and it would not send a signal in every month that is not followed by a crisis $(\mathrm{D}>0)$, so that the number of wrong warning signals $\mathrm{B}$ equals zero.

On the basis of this concept, the overall performance of an indicator $\mathrm{V}_{\mathrm{t}}$ (that is the ability to issue correct signals and to avoid false signals) can be measured by the (adjusted) noise-to-signal ratio $\omega$. This figure is defined as the ratio of 
- the number of false warning signals (= noise) divided by the number of observations in tranquil periods $\mathrm{B} /(\mathrm{B}+\mathrm{D})$ and

- the number of correct warning signals divided by the number observations in the run-up period $\mathrm{A} /(\mathrm{A}+\mathrm{C})$.

Indicators with $\omega>1$ are excluded from the analysis. Following KLR, ${ }^{1}$ another way of interpreting the results of noisiness of the indicators is by comparing the probability of a crisis conditional on a warning signal from the indicator $\mathrm{P}(\mathrm{Crisis} \mid$ warning signal $)=$ $\mathrm{A} /(\mathrm{A}+\mathrm{B})$ with the unconditional probability of a crisis $\mathrm{P}($ Crisis $)=(\mathrm{A}+\mathrm{C}) /(\mathrm{A}+\mathrm{B}+\mathrm{C}+\mathrm{D})$. If the indicator has useful information, then the conditional probability of a crisis should be higher than the unconditional one.

Another measure for the quality of an indicator $\mathrm{V}_{\mathrm{t}}$ is the odds ratio $\zeta$. The odds ratio describes the strength of association between two binary data values. The odds for a currency crisis within 12 months (or not), given a signal $\mathrm{S}_{\mathrm{t}}$ (that is warning signal or not) can be defined in terms of conditional probabilities (Table 2). The odds for a crisis conditional on a warning signal is $[\mathrm{A} /(\mathrm{A}+\mathrm{B})] /[\mathrm{B} /(\mathrm{A}+\mathrm{B})]=\mathrm{A} / \mathrm{B}$. The odds for a crisis conditional on a missing warning signal is $\mathrm{C} /(\mathrm{C}+\mathrm{D})] /[\mathrm{D} /(\mathrm{C}+\mathrm{D})=\mathrm{C} / \mathrm{D}$. Then the odds ratio $\zeta$ is defined as

$\zeta=(\mathrm{A} / \mathrm{B}) /(\mathrm{C} / \mathrm{D})=(\mathrm{A} \bullet \mathrm{D}) /(\mathrm{B} \bullet \mathrm{C})$

An odds ratio of 1 indicates that the event of a currency crisis is equally likely if we observe a crisis warning signal or not. An odds ratio greater than 1 indicates that the crisis is more likely if the indicator has sent a warning signal. And an odds ratio less than 1 indicates that the crisis is even less likely if the indicator has sent a warning signal. Obviously, reasonable indicators have odds ratios greater than $1 .^{2}$

1 See Kaminsky, Lizondo, Reinhart (1998).

2 However, odds-ratios are not symmetric with respect to the ordering of variables. The logarithm of the odds ratio, the difference of the logits of the probabilities, makes the measure symmetric. 
Table 2

Conditional Crisis Probabilities

\begin{tabular}{|l|c|c|}
\hline & $\begin{array}{c}\text { Crisis within } \\
12 \text { months }\end{array}$ & $\begin{array}{c}\text { No crisis within } \\
12 \text { months }\end{array}$ \\
\hline Signal is sent: $S_{\mathbf{t}}=\mathbf{1}$ & $\mathrm{A} /(\mathrm{A}+\mathrm{B})$ & $\mathrm{B} /(\mathrm{A}+\mathrm{B})$ \\
\hline No signal is sent: $\mathbf{S}_{\mathbf{t}}=\mathbf{0}$ & $\mathrm{C} /(\mathrm{C}+\mathrm{D})$ & $\mathrm{D} /(\mathrm{C}+\mathrm{D})$ \\
\hline
\end{tabular}

Finally, in order to discriminate between 'normal' and 'abnormal' behaviour of an individual indicator, the threshold $\delta$ has to be defined. If the cutoff value is set at a rather high level, the indicator is likely to miss all but the most severe crises. In contrast, if the threshold is set very low, the indicator is likely to catch all crises but is also likely to send many false warning signals in tranquil periods. A commonly used way is to set the cut-off value $\delta$ in relation to $\alpha$-percentiles of the distribution of indicator observations, that is $\delta=\mathrm{F}^{-1}(\alpha)$. For example, a possible threshold for the rate of growth of exports would be the set of rates of growth that would leave $75 \%$ of the observations above the cut-off value. This set of growth rates is determined by the first quartile of the frequency distribution (i.e. the $25 \%$ percentile).

A more sophisticated approach is to choose a specific percentile of the frequency distribution. The threshold value can be derived by taking the distribution of the predicted values and the number of turbulences for each country into account. The $\alpha$-percentile might be calculated as the maximum possible number of correct signals prior to currency crisis (here generally 12) in relation to the total number of available observations. Subtracting this value from 1 puts the threshold in the area of the frequency distribution with the high values: ${ }^{1}$

$\alpha=1$ - (Max possible no. of alarms / Total no. of observations)

\footnotetext{
1 See Schnatz, (1999a).
} 
For indicators with an expected sign (-) the expression has to be modified:

$\alpha=($ Max possible no. of alarms / Total no. of observations $)$

In this case the threshold is put in the area of the distribution with low values. ${ }^{1}$

\subsection{Composite Indicators}

Based on the assumption that the greater the number of leading indicators signalling a crisis, the higher the probability that such a crisis would actually occur, KLR proposed a number of composite leading indices. Composite indicators are constructed by weighting together the signals $\mathrm{S}_{\mathrm{r}, \mathrm{t}}$ of $k$ individual indicators $\mathrm{V}_{\mathrm{r}, \mathrm{t}}{ }^{2}$

$\mathrm{S}_{\mathrm{t}}=\sum_{\mathrm{r}=1, \ldots, \mathrm{k}} \mathrm{S}_{\mathrm{r}, \mathrm{t}} \mathrm{W}_{\mathrm{r}}$ and $\sum_{\mathrm{r}=1, \ldots, \mathrm{k}} \mathrm{W}_{\mathrm{r}}=1$

Similar to individual crises indicators, the composite indicator gives a warning signal if it exceeds a critical value $\delta_{\mathrm{S}}$. Once again, the threshold $\delta_{\mathrm{S}}$ is defined in relation to percentiles of the frequency distribution of observations. The percentile is calculated as the maximum possible number of correct signals prior to a currency crisis as a percentage of the total number of available observations. Subtracting this value from 1 puts the threshold in the area of the distribution with high values.

Obviously there are two rules for determining the weights of the specific indicator signals. One approach focuses on equal weights; the other would exploit the observed forecasting performance of the individual indicators before past crises. The latter approach is clearly favourable if future crises are driven by the same economic factors as the past crises, whereas the equal weight approach is neutral.

1 Another specific approach, proposed by KLR, suggests that a grid of reference percentiles (for example percentiles between 10 and 20 percent) should be defined for each individual indicator. Then an 'optimal' rank is found by determining the critical cutoff value (associated with the pre-selected grid) that minimizes the adjusted noise-to-signal ratio

2 See Kaminsky (1998) for a detailed discussion of combining individual indicators. 


\subsection{Calculating Crisis Probabilities}

While composite currency crises indicators show changes in the strength or weakness of crisis warning signals, the index levels cannot be directly interpreted. However, it is possible to assign a particular estimated crisis probability to any value of a composite crisis indicator by dividing the entire sample into several groups, each corresponding to a particular range of the composite indicator, and calculating the proportion of months associated with crises for each group, using the formula

$\mathrm{P}\left(\right.$ crisis $\left.\mid \mathrm{a}<\mathrm{S}_{\mathrm{t}}<\mathrm{b}\right)=\frac{\text { Number of months with } \mathrm{a}<\mathrm{S}_{\mathrm{t}}<\mathrm{b} \text { and a crisis following within } 12 \text { months }}{\text { Number of months with } \mathrm{a}<\mathrm{S}_{\mathrm{t}}<\mathrm{b}}$

where $S_{t}$ is the value of the composite indicator at time $t$, a is the lower bound of a particular range of the index, $\mathrm{b}$ is the upper bound of the range, and $\mathrm{P}\left(\right.$ crisis $\left.\mid \mathrm{a}<\mathrm{S}_{\mathrm{t}}<\mathrm{b}\right)$ is the estimated probability of a crisis occurring within 12 months conditional on $\mathrm{S}_{\mathrm{t}}$ lying in the range between the lower and upper bounds a and $b .{ }^{1}$ In the present study, the entire sample was divided, ranked by the value of the composite indicator, into five groups. The groups are classified in intervals as follows: 0, 0-30, 30-40, 40-50, 50-100. The estimated probabilities are non-linear transformations of the indicators.

\section{Results for Kazakhstan}

\subsection{Observed Currency Crises}

Figure 1 illustrates the conduct of the exchange market pressure index for Kazakhstan. As said before, tensions in the foreign exchange market are identified for periods when the pressure index swings sharply into the negative. For dating a currency crisis, the pressure index $\mathrm{IP}_{\mathrm{t}}$ must exceed its mean 3 times the adjusted MAD (see dotted line).

1 See Zhuang, Dowling (2002) and Knedlik, Scheufele (2007). 
Figure 1

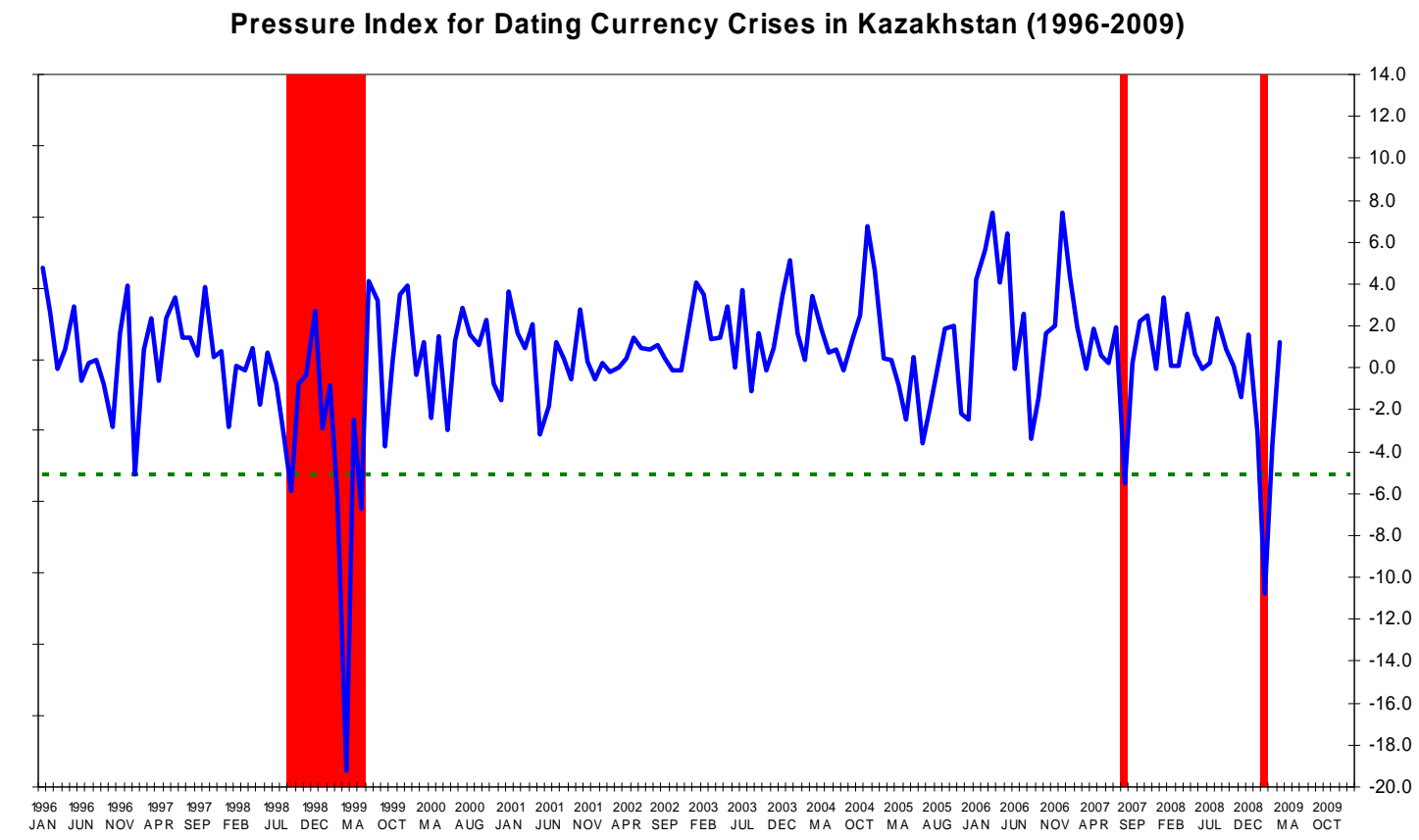

Following these rules, three crisis periods were detected for Kazakhstan (shaded areas). The most prominent observation is the 1998/99 turbulence. The exchange rate devalued from 79.4 Tenge per USD (September 1998) to 130.4 Tenge per USD (June 1999), and the currency reserves dropped in September 1998 by $12.8 \%$ and in March 1999 by 15.4\%. In August 2007 the Banking Crisis took place, accompanied by a remarkable decrease in foreign exchange reserves (Table 3). In February 2009, the National Bank of Kazakhstan defined a new level of exchange rate of the national currency, 150 Tenge per USD $\pm 3 \%$ or \pm 5 Tenge (before: band within 117-123 Tenge per USD or 120 Tenge $\pm 2 \%$ ). Starting from the fourth quarter of 2008 until February, the NBK spent USD 6 bn. (including USD 2.7 bn. in January 2009) to maintain stability in the foreign exchange market. ${ }^{1}$

1 See National Bank of Kazakhstan, press release No. 3, February 4, 2009. 
Table 3

\begin{tabular}{|c|c|}
\hline Period & Description \\
\hline Sep. 1998 - June 1999 & $\begin{array}{l}\text { Exchange rate of the Tenge was devalued from } 79.4 \text { (Sept 1998) to } 130.4 \\
\text { (June 1999) (-40\%). } \\
\text { Foreign exchange reserves dropped by } 12.8 \% \text { (Sept. 1998) and } 15.4 \% \\
\text { (March 1999) respectively. }\end{array}$ \\
\hline August 2007 & Foreign exchange reserves dropped by $15.3 \%$. \\
\hline February 2009 & $\begin{array}{l}\text { Exchange rate of the Tenge was devalued from } 121.3 \text { (Jan. 2009) to } 144.9 \\
\text { (Feb. 2009). }\end{array}$ \\
\hline
\end{tabular}

\subsection{Identifying Individual Indicators for Kazakhstan}

The signal approach proposes the monitoring of a quantity of macroeconomic variables (single indicators) that may tend to show unusual patterns in periods prior to currency turbulences. The following list of individual indicators ${ }^{1}$ with noise-to-signal ratios below unity ${ }^{2}$ displayed a conspicuous behaviour in the year prior to currency turbulences in Kazakhstan, and will be used in this study for that reason.

- Deviation of the real exchange rate from its least absolute deviations trend (LAD trend). A negative value indicates an overvaluation. A multi-country comparison of real exchange rates shows that currencies often tend to be overvalued prior to speculative attacks. The LAD trend minimizes the sum of absolute values of deviations (errors) from the trend line. The least absolute deviations trend is robust in that it is resistant to outliers in the data.

- Export growth. The overvaluation of a currency should have repercussions on trade flows. Export growth often declines in the run-up to currency crises, including the

\footnotetext{
For a detailed discussion see Schnatz (1998) and Ahec-Šonje and Babić (2003).

2 Individual indicators with noise-to-signal ratios of above one were excluded from the analyses.
} 
period prior to the outbreak of the crises.

- Balance on current account as a share of GDP. Current account deficits (as a percentage of GDP) were typically higher prior to speculative attacks than in tranquil periods. Not only the loss of international competitiveness, which should show up already in a deterioration of the trade account, but also the funds necessary to service international debts, which is reflected in the current account position, may have been important for assessing a country's vulnerability to speculative attacks.

- Growth of domestic credit as a share of GDP. The growth of domestic credit as a percentage of GDP could indicate that a country is conducting an excessively expansionary economic policy. Moreover, a large level of domestic credit growth could also indicate excessive lending financed by an exchange-rate-orientated monetary policy.

- Change of oil price (Brent). Energy (production of crude oil and natural gas) is the leading economic sector in Kazakhstan.

- Real interest rate. An increase of real interest rates could mean shrinking liquidity in the financial system of a country.

- Growth of real GDP. The overvaluation of a currency should dampen economic activity.

- Money Supply. An increase in M1 means that the monetary policy is expansionary, causing pressure for the domestic currency.

- Lending/deposit interest rates differential. A widening lending to deposit rate differential can signal a risk increase and deterioration of bank portfolios, as well as lack of competition and supervisory and regulatory weaknesses.

- External debt as a share of GDP. A growing external dept to GDP ratio often signals an increasing external vulnerability. 
The ten individual indicators for Kazakhstan were analysed according to the methods of KLR. The results are summarised in Table 4. Thresholds were calculated for the time span January 1997 to December 2007. Table 4 also shows the expected sign (+ high values; - low values) of the individual indicators in periods prior to currency turbulences.

Table 4

Performance of Individual Currency Crises Indicators

\begin{tabular}{|c|c|c|c|c|c|c|c|}
\hline & $\begin{array}{c}\text { Expected } \\
\text { sign } \\
\text { before } \\
\text { crises } \\
(1) \\
\end{array}$ & $\begin{array}{c}\text { Good signals } \\
\text { as percentage } \\
\text { of possible } \\
\text { good signals } \\
(2) \\
\end{array}$ & \begin{tabular}{|c|} 
Bad signals \\
as percentage \\
of possible \\
bad signals \\
$(3)$ \\
\end{tabular} & $\begin{array}{c}\text { Adjusted } \\
\text { noise-to- } \\
\text { signal-ratio } \\
\\
(4) \\
\end{array}$ & $\begin{array}{l}\text { Odds- } \\
\text { Ratio } \\
\text { (5) } \\
\end{array}$ & \begin{tabular}{|c|}
$\begin{array}{c}\mathrm{P}(\text { Crisis } \\
\text { signal })\end{array}$ \\
\\
$(6)$ \\
\end{tabular} & $\begin{array}{c}\mathrm{P}(\text { Crisis | } \\
\text { signal) } \\
-\mathrm{P}(\text { crises }) \\
\\
(7) \\
\end{array}$ \\
\hline In terms of the classification table 2 & & $A(A+C)$ & $B /(B+D)$ & $\begin{array}{l}{[B /(B+D)] /} \\
{[A /(A+C)]}\end{array}$ & $\left(A^{*} D\right) /\left(B^{*} C\right)$ & $A /(A+B)$ & $\begin{array}{c}\mathrm{A} /(\mathrm{A}+\mathrm{B})- \\
(\mathrm{A}+\mathrm{C}) /(\mathrm{A}+\mathrm{B}+\mathrm{C}+\mathrm{D})\end{array}$ \\
\hline $\begin{array}{l}\text { Real exchange rate (dev. from LAD trend) } \\
\text { Export } \\
\text { CAB/GDP } \\
\text { Credits to economy/GDP } \\
\text { External debt/GDP } \\
\text { Oil price (Brent) } \\
\text { Real GDP } \\
\text { Lending /deposit interest rates differencial } \\
\text { Money supply } \\
\text { Real interest rate }\end{array}$ & $\begin{array}{l}- \\
- \\
- \\
+ \\
+ \\
- \\
- \\
+ \\
+ \\
+\end{array}$ & $\begin{array}{l}0.50 \\
0.33 \\
0.42 \\
0.63 \\
0.38 \\
0.54 \\
0.33 \\
0.38 \\
0.38 \\
0.42\end{array}$ & $\begin{array}{l}0.12 \\
0.16 \\
0.14 \\
0.09 \\
0.15 \\
0.11 \\
0.16 \\
0.16 \\
0.15 \\
0.14\end{array}$ & $\begin{array}{l}0.25 \\
0.49 \\
0.35 \\
0.15 \\
0.41 \\
0.21 \\
0.49 \\
0.44 \\
0.41 \\
0.35\end{array}$ & $\begin{array}{c}7.08 \\
2.53 \\
4.23 \\
16.30 \\
3.28 \\
9.24 \\
2.53 \\
3.04 \\
3.28 \\
4.23\end{array}$ & $\begin{array}{l}0.50 \\
0.33 \\
0.42 \\
0.63 \\
0.38 \\
0.54 \\
0.33 \\
0.36 \\
0.38 \\
0.42\end{array}$ & $\begin{array}{l}0.30 \\
0.13 \\
0.22 \\
0.43 \\
0.18 \\
0.34 \\
0.13 \\
0.16 \\
0.18 \\
0.22\end{array}$ \\
\hline
\end{tabular}

\section{Conduct of Composite Indicators}

\subsection{Signal Approach}

As composite leading indices contain more information and are in general more reliable than single indicators, they are used for predicting crises. The first approach focuses on the traditional signal method. Under the signal approach, composite indicators are constructed by weighting together the signals of individual indicators. Indicator S1 gives equal weights $(=1 / 10)$ to all individual signal variables $S_{r}$

$\mathrm{S} 1_{\mathrm{t}}=\sum_{\mathrm{r}=1, \ldots, 10} \mathrm{~S}_{\mathrm{r}, \mathrm{t}} 1 / 10$

In any month, we can observe between zero and ten warning signals, so $0 \geq \mathrm{S} 1_{\mathrm{t}} \leq 1$. 
A second indicator uses the information on the forecasting accuracy of each single indicator $\mathrm{S}_{\mathrm{r}}$ by exploiting the specific noise-to-signal ratios $\omega_{\mathrm{r}}=\left[\mathrm{B}_{\mathrm{r}} /\left(\mathrm{B}_{\mathrm{r}}+\mathrm{D}_{\mathrm{r}}\right)\right] /\left[\mathrm{A}_{\mathrm{r}} /\left(\mathrm{A}_{\mathrm{r}}+\mathrm{C}_{\mathrm{r}}\right)\right]$ :

$\mathrm{S} 2_{\mathrm{t}}=\sum_{\mathrm{r}=1, \ldots, 10} \mathrm{~S}_{\mathrm{r}, \mathrm{t}}\left[\left(1 / \omega_{\mathrm{r}}\right) / \sum_{\mathrm{r}=1, \ldots, 10} 1 / \omega_{\mathrm{r}}\right]$

Here the signals of the individual indicators are weighted by the inverse of their adjusted noise-to-signal ratios, which were divided by the sum of the inverse noise-tosignal ratios to add up to unity. Composite indicator 2 gives more weight to the signalling behaviour of individual indicators with low noise-to-signal ratios.

Composite indicator 3 uses the information coming from the specific odds-ratios $\zeta_{\mathrm{r}}=\left(\mathrm{A}_{\mathrm{r}} \bullet \mathrm{D}_{\mathrm{r}}\right) /\left(\mathrm{B}_{\mathrm{r}} \bullet \mathrm{C}_{\mathrm{r}}\right)$ of the single indicators $\mathrm{S}_{\mathrm{r}}$ :

$$
\mathrm{S} 3_{\mathrm{t}}=\sum_{\mathrm{r}=1, \ldots, 10} \mathrm{~S}_{\mathrm{r}, \mathrm{t}} \bullet\left[\zeta_{\mathrm{r}} / \sum_{\mathrm{r}=1, \ldots, 10} \zeta_{\mathrm{r}}\right]
$$

This indicator gives more weight to the signalling behaviour of individual indicators with high odds-ratios.

Figures 2a-2c shows the conduct of the three composite indicators in Kazakhstan. Crises periods are represented by shaded areas. The dotted line shows the specific indicator thresholds $\delta_{\mathrm{S}}$. The composite indicators send a warning signal whenever they move above the critical value. As said before, the estimation period for the critical thresholds reaches from January 1997 to December 2007, thus allowing an out-of-sample test with the most recent crisis in Kazakhstan, which happened in February 2009. In addition, the estimated crises probabilities are shown in figures 3a-3c. Here the dotted lines mark the $50 \%$ probability for a currency crisis. 
Fig. 2a-2c
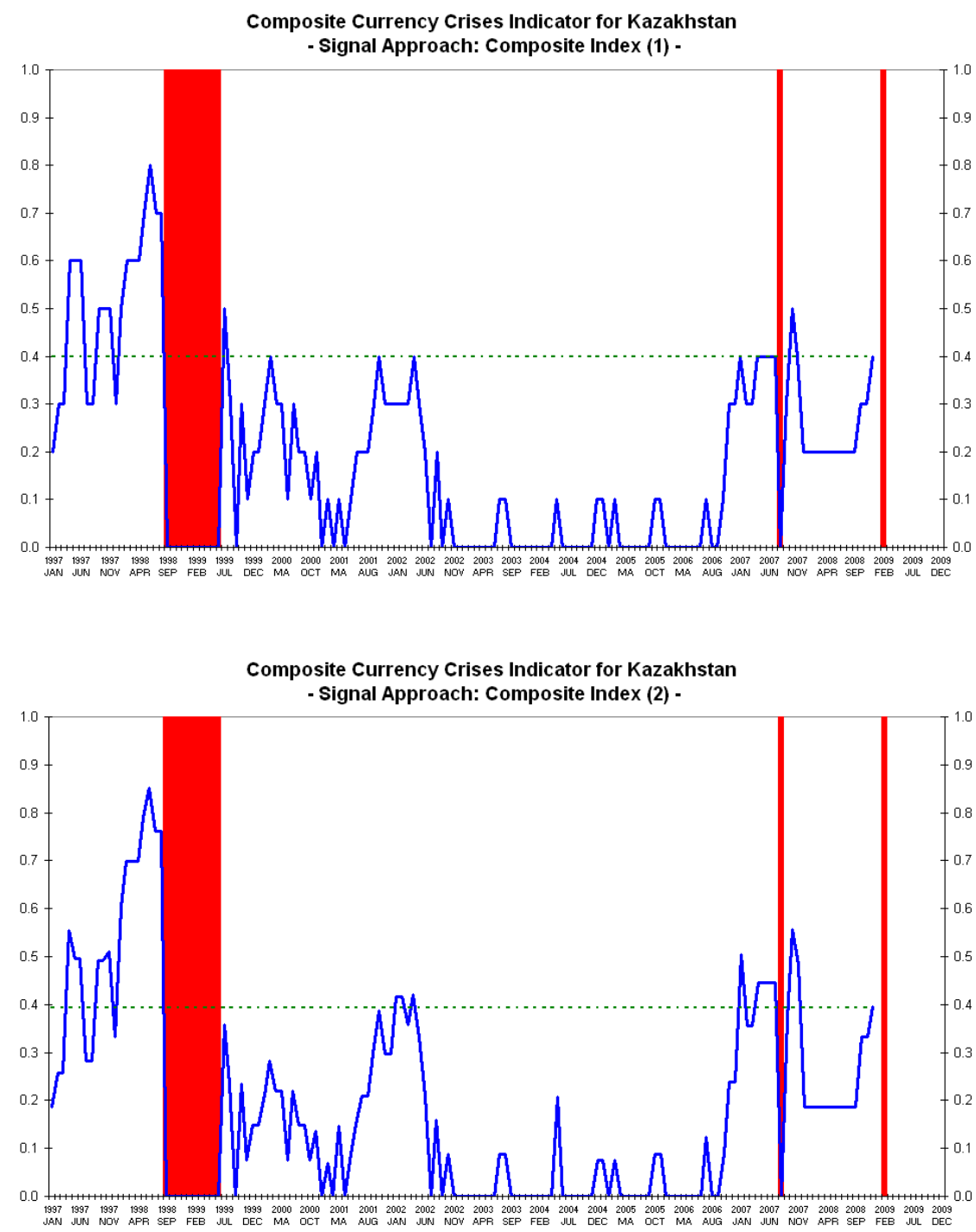

Composite Currency Crises Indicator for Kazakhstan - Signal Approach: Composite Index (3) -

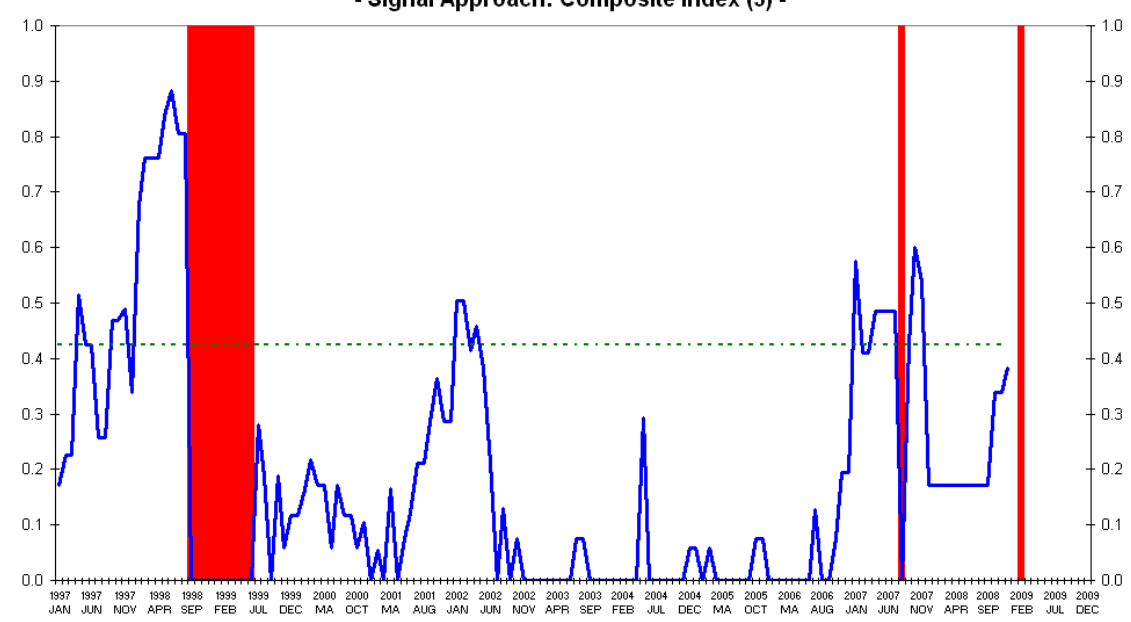


Fig. 3a-3c

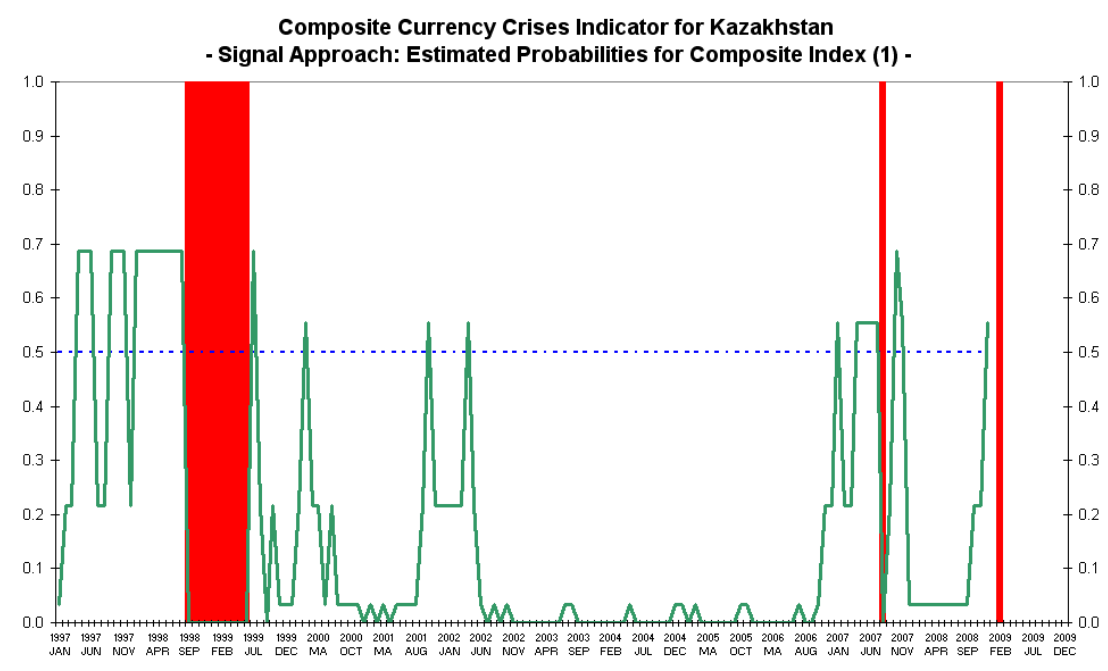

Composite Currency Crises Indicator for Kazakhstan

- Signal Approach: Estimated Probabilities for Composite Index (2) -

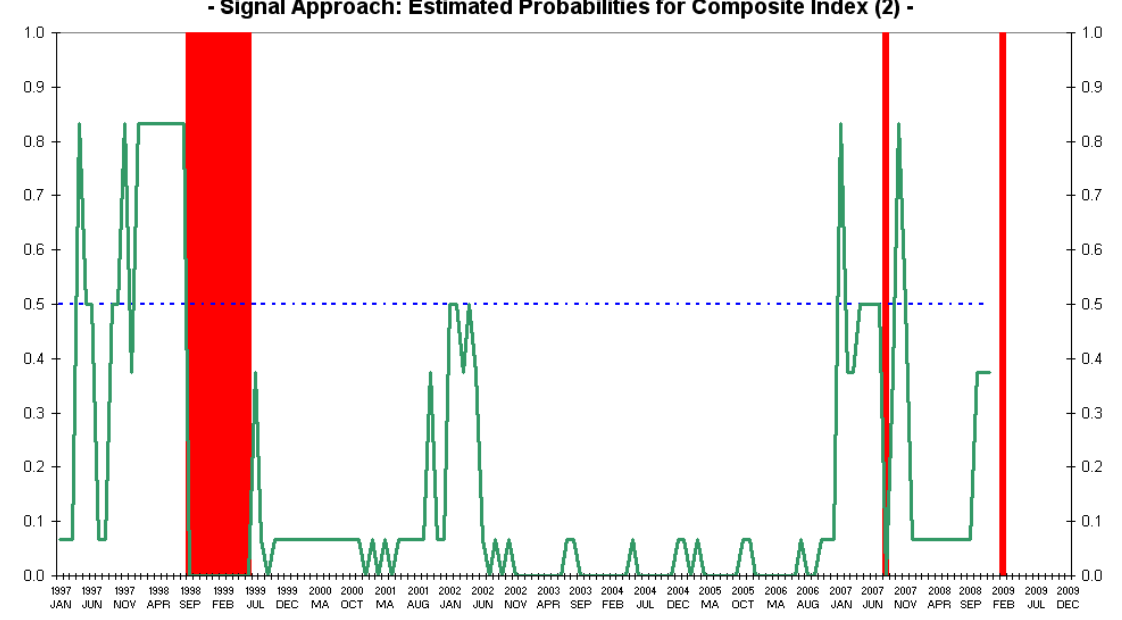

Composite Currency Crises Indicator for Kazakhstan

- Signal Approach: Estimated Probabilities for Composite Index (3) -

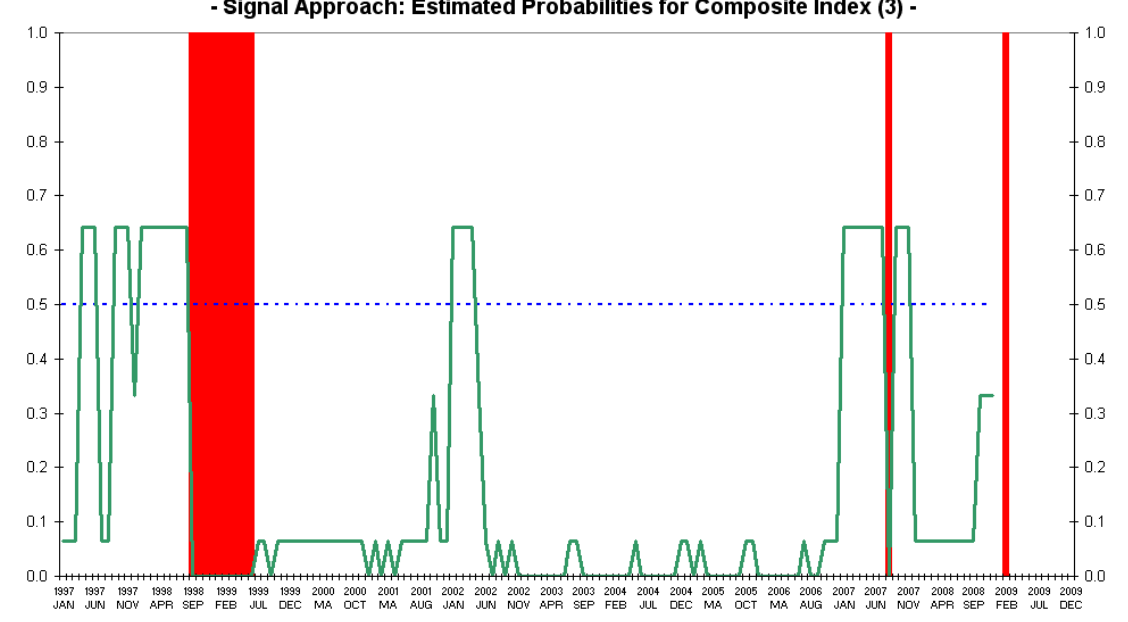




\subsection{Mixed approach: Principal Components and Single Indicators}

A larger number of indicators can be firstly condensed with the help of principal component analysis (PCA). ${ }^{1}$ PCA involves a mathematical procedure that transforms a number of possibly correlated variables into a smaller number of uncorrelated variables called principal components. The first principal component accounts for as much variability (measured by variance) in the data as possible. Each succeeding component accounts for as much of the remaining variability as possible, under the constraint that every principal component is uncorrelated with the preceding ones. Mathematically, PCA leads to a eigenvalue decomposition of the covariance or, as in this analysis of the correlation matrix of the leading indicators. The eigenvectors give the weighting scheme of the indicators, and the corresponding eigenvalues are equal to the variance, explained by the corresponding principal component. From the eigenvalue decomposition as many eigenvectors as indicators results. To condense the information contained in the whole indicator set, only a few principal components are extracted and used in the signal approach. So the question is how many components are needed to provide an adequate summary of a given data set? Here a relative ad hoc procedure is used. Only principal components with eigenvalues greater than one are chosen. This simple procedure is called Kaiser criterion. In a second step the components are examined for plausibility.

Here a mixed approach is pursued. On the one hand two predominant individual indicators, namely the real exchange rate (deviation from LAD trend) ${ }^{2}$ and the change of oil price, are used as input for the composite indicator; on the other hand the principal components with eigenvalues greater than one of the remaining eight indicators. For the identification of the "expected sign" of the principal components before currency crises, a cross-correlation analysis with the pressure index for the time-span January 1997 to

\footnotetext{
See Jolliffe I.T. (2002).

2 A multi-country comparison of real exchange rates shows that currencies often tend to be overvalued prior to speculative attacks.
} 
December 2000 was carried out. The inverse direction of the observed largest crosscorrelation was taken for the expected sign of the principal component.

Indicator S4 gives equal weights to the warning signals of the five individual input series. Indicator S5 uses the information on the forecasting accuracy of each input series by exploiting the specific noise-to-signal ratios. Once again the warning signals are weighted by the inverse of their adjusted noise-to-signal ratios. Finally indicator S6 uses the odd-ratios of the input series as a weighting scheme. Figures $4 a-4 c$ present the composite indicators, figures $5 \mathrm{a}-5 \mathrm{c}$ the estimated crises probabilities.

Obviously, there is no unambiguous composite indicator that shows best results for Kazakhstan (see table 5). This finding is not very astonishing, taking into account that all time-series are relatively short and that there are only two observed currency turbulences in the in-sample-period 1997 to 2007. However, the noise-to-signal ratios of all composite crises indicators are well below unity. Consequently, all indicators exhibit useful information (see columns five to seven in table 5). The estimated conditional probability for a currency crisis $\mathrm{P}($ Crisis $\mid$ signal) is in all cases higher than the unconditional probability for a crisis. Furthermore, the odds ratios are clearly above one. An odds ratio greater than one indicates, that a crisis is more likely if the indicator has sent a warning signal.

Table 5

Performance of Composite Currency Crises Indicators

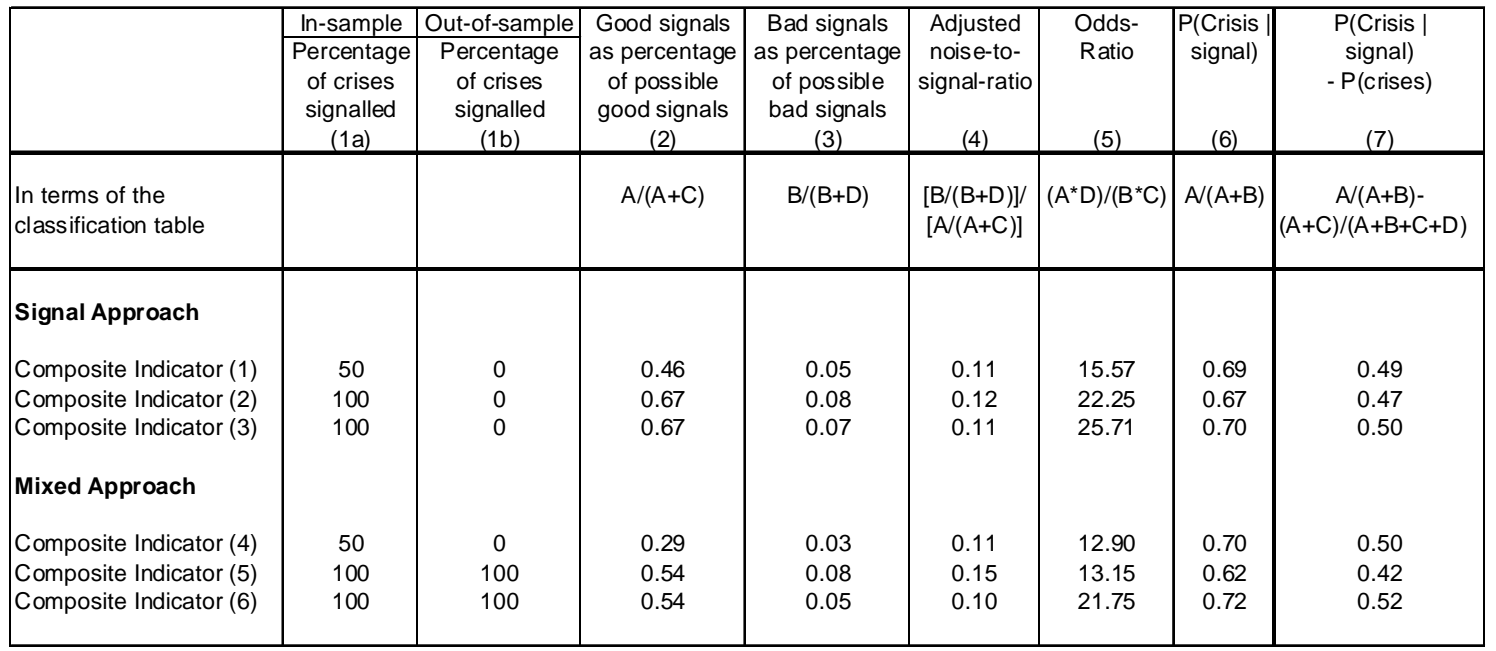


Fig.4a-4c

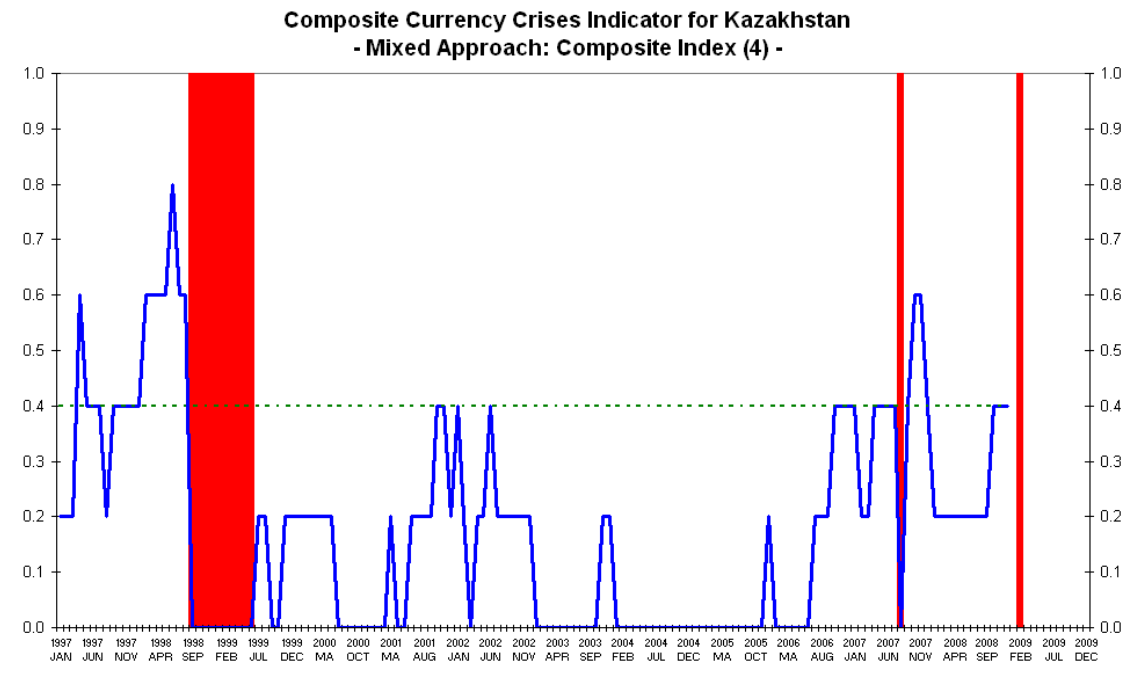

Composite Currency Crises Indicator for Kazakhstan

- Mixed Approach: Composite Index (5)

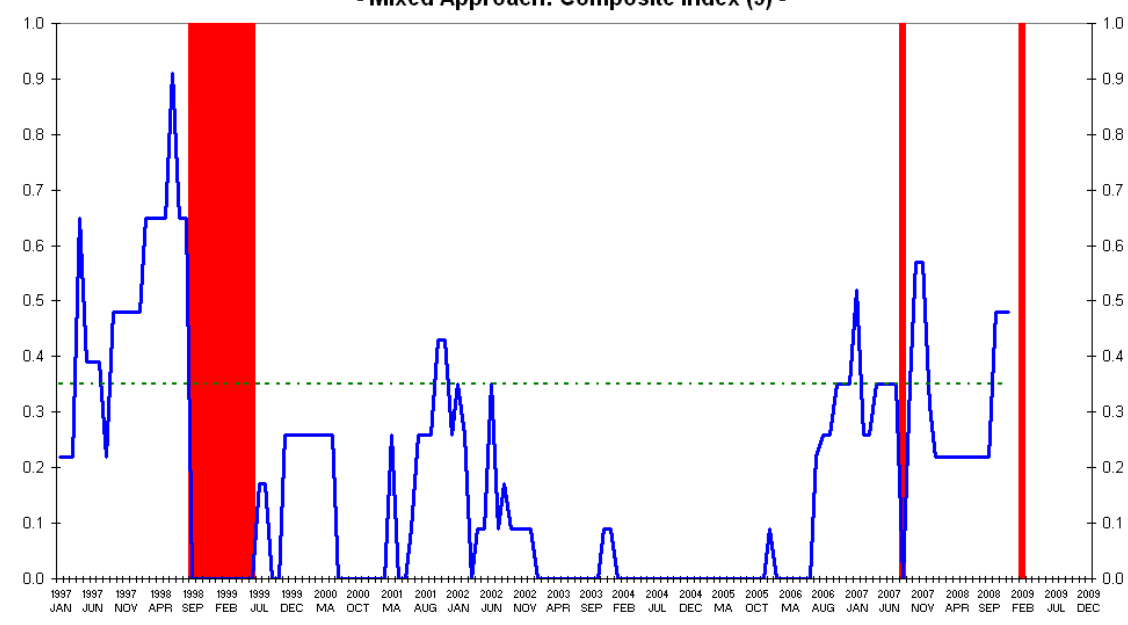

Composite Currency Crises Indicator for Kazakhstan

- Mixed Approach: Composite Index (6) -

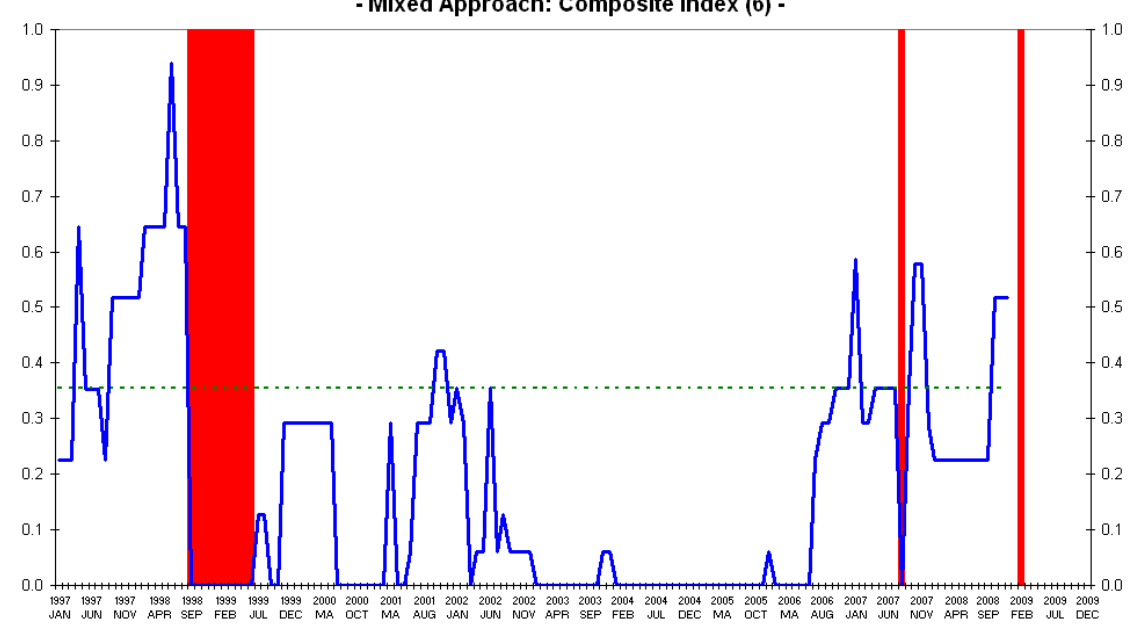


Fig. 5a-5c

Composite Currency Crises Indicator for Kazakhstan

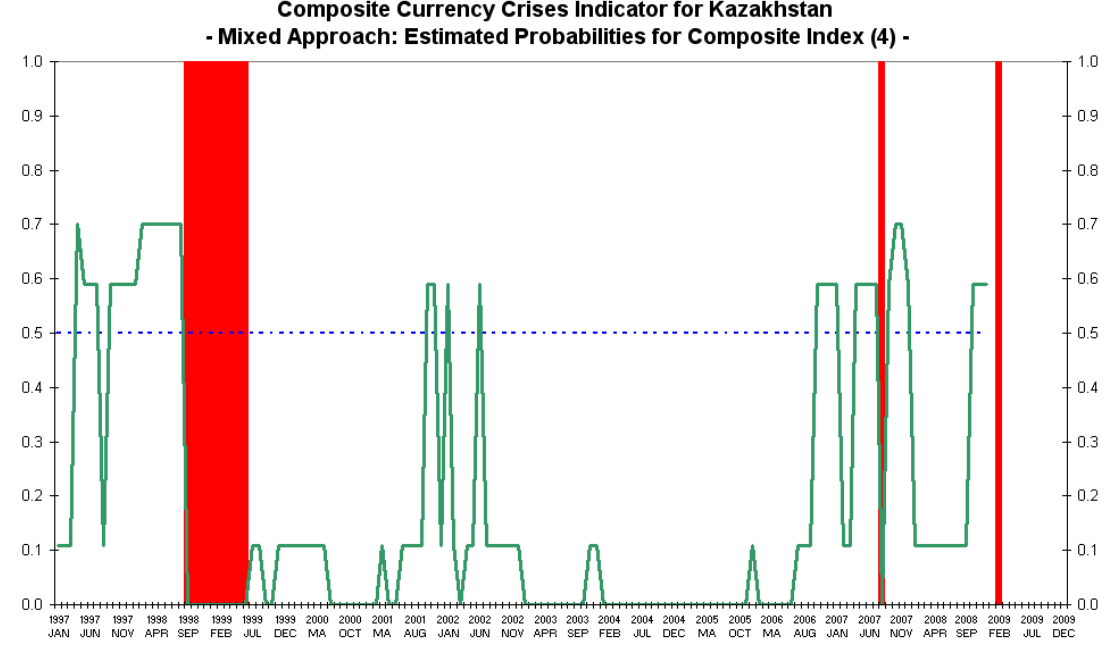

Composite Currency Crises Indicator for Kazakhstan

- Mixed Approach: Estimated Probabilities for Composite Index (5) -

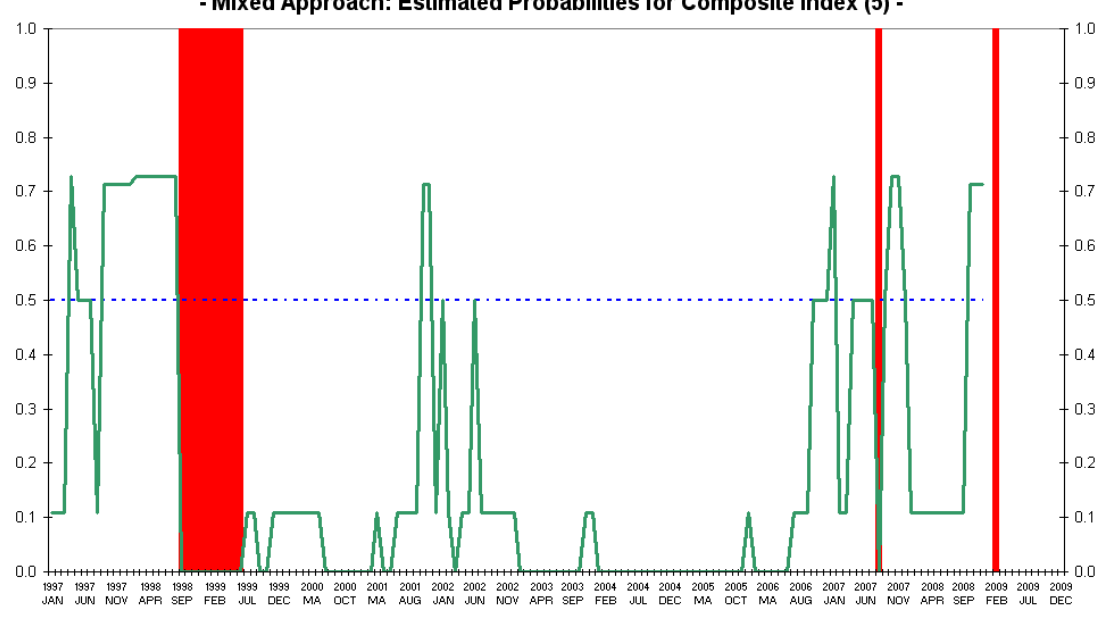

Composite Currency Crises Indicator for Kazakhstan - Mixed Approach: Estimated Probabilities for Composite Index (6) -

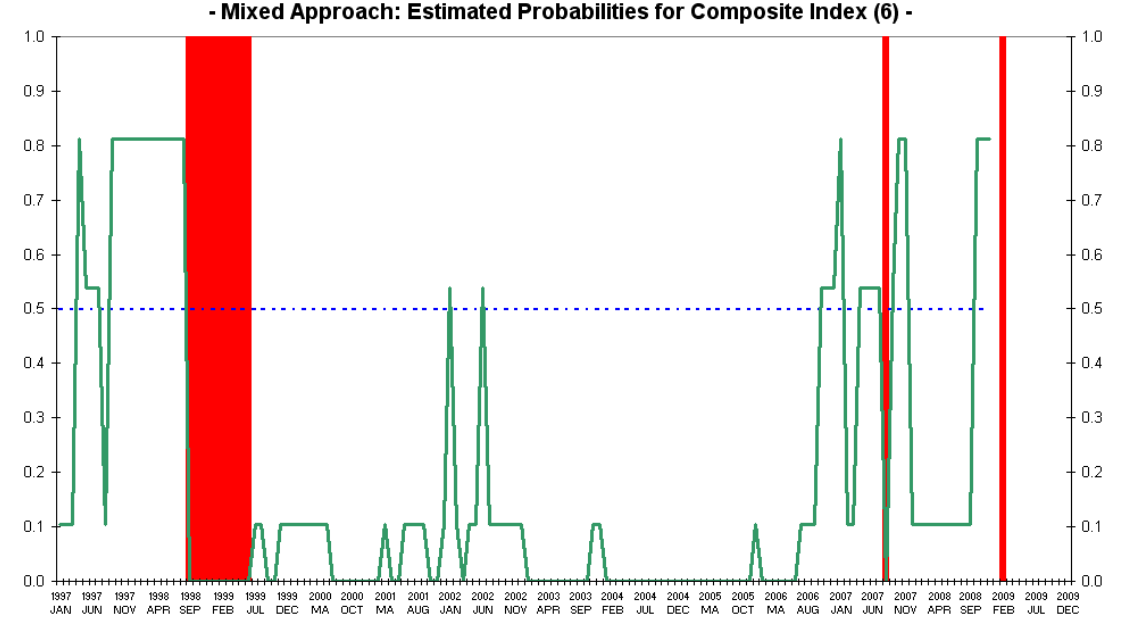


Indicator 1 as well as indicator 4 miss the 2007 crisis, the remaining four indicators signal all crises in the in-sample-period 1997 to 2007. Concerning the out-of-sample-crisis 2009 , only indicators 5 and 6 from the mixed approach gave correct warning signals in the preceding year 2008. Finally, indicators 2 and 3 as well as indicators 5 and 6 showed some false alarms in 2001/2002.

\section{Annex}

\section{Annotation: Model Based Approaches}

For the analysis of currency crises besides the signal approach also model based parametric methods are applied in the literature. These approaches include nonlinear regression models like logit regressions. Another model based approach is Markov regimeswitching (MRS). This is briefly discussed in the sequel.

In modern statistics, non-linear time series methods are increasingly being used for the modeling of structural breaks and regime-dependent dynamics. Markov regimeswitching models are prominent examples in which the model parameters depend on stochastic regime variables. With this approach a model that is in itself linear becomes more flexible because the parameters can take on different values, depending on the regime in which the time series is found. In this way in the modeling process it can be taken into consideration that the dynamics vary over time. Since the time points of the regime change do not need to be provided in advance but can be estimated during the calculations, this model type can also be used for the dating of currency crises.

Concretely, the foreign exchange market index $\mathrm{IP}_{\mathrm{t}}$ is assumed to depend on a nonobservable status variable $\mathrm{s}_{\mathrm{t}}$, which is designated as the status or regime at point-oftime $\mathrm{t}$. The number of cyclical regimes in this study is limited to two. For $\mathrm{s}_{\mathrm{t}}=1$, status 1 (crisis period) applies; for $\mathrm{s}_{\mathrm{t}}=2$, status 2 applies (tranquil period). The probability with which the regime changes from one period to the other period (or remains in one) is assumed to be time-invariant and depends only on the state of the previous period $\mathrm{s}_{\mathrm{t}-1}$ 
$p\left(s_{t}=i \mid s_{t-1}=j\right)=p_{i j} ; \quad i, j=1,2$

With a Markov process with two states, there are a total of four transition probabilities. For these $\mathrm{p}_{1}+\mathrm{p}_{12}=\mathrm{p}_{22}+\mathrm{p}_{21}=1$ applies; the status variable $\mathrm{s}_{\mathrm{t}}$ thus follows a Markov process of the first degree. The distribution of $\operatorname{IP}_{t}$ (with a given state of $i$ ) is described by the density function $\mathrm{f}$

$\mathrm{f}\left(\mathrm{IP}_{\mathrm{t}} \mid \mathrm{s}_{\mathrm{t}}=\mathrm{i}, \mu_{\mathrm{i}}, \boldsymbol{\mathbf { B }}, \sigma^{2}\right)=1 /\left(2 \pi \sigma^{2}\right)^{1 / 2} \exp \left[-(1 / 2)\left(\mathrm{IP}_{\mathrm{t}}-\mu_{\mathrm{i}}-\mathbf{Z}_{\mathrm{t}} \mathbf{B}\right)^{2} / \sigma^{2}\right]$

i.e., $\mathrm{IP}_{\mathrm{t}}$ is normally distributed with a state-dependent mean value $\mu_{\mathrm{i}}+\mathbf{Z}_{\mathrm{t}} \mathbf{\mathbf { B }}$ and constant variance $\sigma^{2} . \mathbf{Z}_{\mathrm{t}}$ is a vector of indicators at time $t$ and $\boldsymbol{\beta}$ is a vector of non-switching regression parameters. For state $1, \mu_{1}$ applies, otherwise $\mu_{2}$. The vector of parameters to be estimated $\left(\mathrm{p}_{11}, \mathrm{p}_{22}, \mu_{1}, \mu_{2}, \boldsymbol{\beta}, \sigma^{2}\right)$ of the MS model is designated with the symbol $\boldsymbol{\theta} .{ }^{1}$ The MRS model can be estimated with the maximum-likelihood method, in which in the calculation practice numeric optimisation methods are employed due to non-linearities. ${ }^{2}$

At the same time, the procedure supplies, in addition to estimations of the parameter vector $\boldsymbol{\theta}$, also a quantification of regime probabilities depending on amount the of information considered in each case: The probability $p\left(s_{t}=i \mid I_{T}\right)$ designates the conditional probability of being at point $t$ in regime $i$, in the case that the entire amount of information is conditioned (smoothed probability) in estimation period $[1, \ldots, \mathrm{T}]$ of the MRS model. The probability $\mathrm{p}\left(\mathrm{s}_{\mathrm{t}}=\mathrm{i} \mid \mathrm{I}_{\mathrm{t}}\right)$, on the other hand, describes the conditional probability for state $\mathrm{i}$, in the case that the focus is only on the amount of information available up to the calculating period $t$ (filtered probability). For the final point-of-time $\mathrm{T}$, the filtered value corresponds to the smoothed value. Both regime probabilities may serve as composite currency crisis indicators.

1 The probability $\mathrm{p}_{12}$, which is also unknown and to be estimated, follows from the relationship $1-\mathrm{p}_{11}$; the probability $\mathrm{p}_{21}$ from $1-\mathrm{p}_{22}$.

2 For a time-varying specification of transition probabilities $\mathrm{p}_{\mathrm{ij}}$ and variance $\sigma^{2}$, see Abiad (2003) and Knedlik, Scheufele (2007). 


\section{References}

Abiad, A. (2003), Early Warning Systems: A Survey and a Regime-Switching Approach, IMF Working Paper, WP/02/32.

Ahec-Šonje, A., Babić, A. (2003), Measuring and Predicting Currency Disturbances: The "Signals" Approach, EKONOMSKI PREGLED, 54 (1-2) 3-37..

Berg, A., Pattillo, C. (1999), Are Currency Crises Predictable? A Test, IMF Staff Papers, 46(2), 107-138.

Deutsche Bundesbank (1999), The Role of Economic Fundamentals in the Emergence of Currency Crises in Emerging Markets, in: Monthly Reports of the Deutsche Bundesbank, 15-27.

Frankel J. A, Rose, A. K. (1996), Currency Crashes in Emerging Markets: An Empirical Treatment, Journal of International Economics, Vol. 41, 351-366.

Jolliffe I.T. (2002), Principal Component Analysis, Series: Springer Series in Statistics, 2nd ed., Springer, NY.

Kaminsky, G., Lizondo, S., Reinhart, C. M. (1998), Leading Indicators of Currency Crisis, IMF Staff Papers, 45(1), 1-49.

Kaminsky, G. (1998), Currency and Banking Crises: The Early Warnings of Distress, Board of Governors of the Federal Reserve System, International Finance Discussion Papers 629, 1-28.

Knedlik, T., Scheufele R. (2007), Three methods of forecasting currency crises: Which made the run in signaling the South African currency crisis of June 2006?, IWHDiscussions Papers, Nr. 17.

Nierhaus, W. (2000), Currency Crises Indicators - The Signal Approach, 25th CIRET Conference, Paris.

Schnatz, B. (1998), Macroeconomic Determinants of Currency Turbulences in Emerging Markets, Deutsche Bundesbank Discussion Paper No. 3/98, Economic Research Group of the Deutsche Bundesbank.

Schnatz, B. (1999a) Currency Crises in Emerging Markets - The Case of Turkey, mimeo.

Schnatz, B. (1999b), The Sudden Freeze of the Asian Miracle: The Role of Macroeconomic Fundamentals, Asian-Pacific Journal of Finance, Vol. 2, No. 1. 
Zhuang J., Dowling J. M. (2002), Causes of the 1997 Asian Financial Crisis: What Can an Early Warning System Model Tell Us? Asian Development Bank, ERD working paper series no. 26. 


\section{CESifo Working Paper Series}

for full list see www.cesifo-group.org/wp

(address: Poschingerstr. 5, 81679 Munich, Germany, office@cesifo.de)

2709 Jon H. Fiva and Gisle James Natvik, Do Re-election Probabilities Influence Public Investment?, July 2009

2710 Jarko Fidrmuc and Iikka Korhonen, The Impact of the Global Financial Crisis on Business Cycles in Asian Emerging Economies, July 2009

2711 J. Atsu Amegashie, Incomplete Property Rights and Overinvestment, July 2009

2712 Frank R. Lichtenberg, Response to Baker and Fugh-Berman's Critique of my Paper, "Why has Longevity Increased more in some States than in others?", July 2009

2713 Hans Jarle Kind, Tore Nilssen and Lars Sørgard, Business Models for Media Firms: Does Competition Matter for how they Raise Revenue?, July 2009

2714 Beatrix Brügger, Rafael Lalive and Josef Zweimüller, Does Culture Affect Unemployment? Evidence from the Röstigraben, July 2009

2715 Oliver Falck, Michael Fritsch and Stephan Heblich, Bohemians, Human Capital, and Regional Economic Growth, July 2009

2716 Wladimir Raymond, Pierre Mohnen, Franz Palm and Sybrand Schim van der Loeff, Innovative Sales, R\&D and Total Innovation Expenditures: Panel Evidence on their Dynamics, July 2009

2717 Ben J. Heijdra and Jochen O. Mierau, Annuity Market Imperfection, Retirement and Economic Growth, July 2009

2718 Kai Carstensen, Oliver Hülsewig and Timo Wollmershäuser, Price Dispersion in the Euro Area: The Case of a Symmetric Oil Price Shock, July 2009

2719 Katri Kosonen and Gaëtan Nicodème, The Role of Fiscal Instruments in Environmental Policy, July 2009

2720 Guglielmo Maria Caporale, Luca Onorante and Paolo Paesani, Inflation and Inflation Uncertainty in the Euro Area, July 2009

2721 Thushyanthan Baskaran and Lars P. Feld, Fiscal Decentralization and Economic Growth in OECD Countries: Is there a Relationship?, July 2009

2722 Nadia Fiorino and Roberto Ricciuti, Interest Groups and Government Spending in Italy, 1876-1913, July 2009

2723 Andreas Wagener, Tax Competition, Relative Performance and Policy Imitation, July 2009 
2724 Hans Fehr and Fabian Kindermann, Pension Funding and Individual Accounts in Economies with Life-cyclers and Myopes, July 2009

2725 Ernesto Reuben and Arno Riedl, Enforcement of Contribution Norms in Public Good Games with Heterogeneous Populations, July 2009

2726 Kurt Schmidheiny and Marius Brülhart, On the Equivalence of Location Choice Models: Conditional Logit, Nested Logit and Poisson, July 2009

2727 Bruno S. Frey, A Multiplicity of Approaches to Institutional Analysis. Applications to the Government and the Arts, July 2009

2728 Giovanni Villani, A Strategic R\&D Investment with Flexible Development Time in Real Option Game Analysis, July 2009

2729 Luca Di Corato and Michele Moretto, Investing in Biogas: Timing, Technological Choice and the Value of Flexibility from Inputs Mix, July 2009

2730 Gilad D. Aharonovitz, Nathan Skuza and Faysal Fahs, Can Integrity Replace Institutions? Theory and Evidence, July 2009

2731 Michele Moretto and Sergio Vergalli, Managing Migration through Conflicting Policies: an Option-theory Perspective, July 2009

2732 Volker Nitsch, Fly or Cry: Is Airport Noise Costly?, July 2009

2733 Francesco Cinnirella and Joachim Winter, Size Matters! Body Height and Labor Market Discrimination: A Cross-European Analysis, July 2009

2734 Samuel Bowles and Sandra Polanía Reyes, Economic Incentives and Social Preferences: A Preference-based Lucas Critique of Public Policy, July 2009

2735 Gary Burtless, Lessons of the Financial Crisis for the Design of National Pension Systems, July 2009

2736 Helmuth Cremer, Firouz Gahvari and Pierre Pestieau, Fertility, Human Capital Accumulation, and the Pension System, July 2009

2737 Hans Jarle Kind and Frank Stähler, Market Shares in Two-Sided Media Industries, July 2009

2738 Pamela Campa, Alessandra Casarico and Paola Profeta, Gender Culture and Gender Gap in Employment, August 2009

2739 Sebastian Gechert, Supplementary Private Health Insurance in Selected Countries: Lessons for EU Governments?, August 2009

2740 Leif Danziger, Endogenous Monopsony and the Perverse Effect of the Minimum Wage in Small Firms, August 2009 
2741 Yan Dong and John Whalley, A Third Benefit of Joint Non-OPEC Carbon Taxes: Transferring OPEC Monopoly Rent, August 2009

2742 Valentina Bosetti, Carlo Carraro and Massimo Tavoni, Climate Change Mitigation Strategies in Fast-Growing Countries: The Benefits of Early Action, August 2009

2743 Christina Felfe, The Willingness to Pay for Job Amenities: Evidence from Mothers' Return to Work, August 2009

2744 Jörg Franke, Christian Kanzow, Wolfgang Leininger and Alexandra Väth, Effort Maximization in Asymmetric N-Person Contest Games, August 2009

2745 Bruno S. Frey and Paolo Pamini, Making World Heritage Truly Global: The Culture Certificate Scheme, August 2009

2746 Frank N. Caliendo, Is Social Security behind the Collapse of Personal Saving?, August 2009

2747 Caterina Liesegang and Marco Runkel, Corporate Income Taxation of Multinationals and Fiscal Equalization, August 2009

2748 Chrysovalantou Milliou and Apostolis Pavlou, Upstream Horizontal Mergers and Efficiency Gains, August 2009

2749 Rüdiger Pethig and Christian Wittlich, Interaction of Carbon Reduction and Green Energy Promotion in a Small Fossil-Fuel Importing Economy, August 2009

2750 Kai Carstensen, Oliver Hülsewig and Timo Wollmershäuser, Monetary Policy Transmission and House Prices: European Cross-country Evidence, August 2009

2751 Olaf Posch, Explaining Output Volatility: The Case of Taxation, August 2009

2752 Beatrice Scheubel, Daniel Schunk and Joachim Winter, Don't Raise the Retirement Age! An Experiment on Opposition to Pension Reforms and East-West Differences in Germany, August 2009

2753 Daniel G. Arce, Dan Kovenock and Brian Roberson, Suicide Terrorism and the Weakest Link, August 2009

2754 Mario Larch and Wolfgang Lechthaler, Comparative Advantage and Skill-Specific Unemployment, August 2009

2755 Horst Raff and Nicolas Schmitt, Buyer Power in International Markets, August 2009

2756 Seppo Kari, Hanna Karikallio and Jukka Pirttilä, The Impact of Dividend Taxation on Dividends and Investment: New Evidence Based on a Natural Experiment, August 2009

2757 Mirco Tonin and Michael Vlassopoulos, Disentangling the Sources of Pro-social Behavior in the Workplace: A Field Experiment, August 2009 
2758 Nicole Grunewald and Inmaculada Martínez-Zarzoso, Driving Factors of Carbon Dioxide Emissions and the Impact from Kyoto Protocol, August 2009

2759 Yu-Fu Chen and Michael Funke, Booms, Recessions and Financial Turmoil: A Fresh Look at Investment Decisions under Cyclical Uncertainty, August 2009

2760 Jan-Egbert Sturm and Jakob de Haan, Does Central Bank Communication really Lead to better Forecasts of Policy Decisions? New Evidence Based on a Taylor Rule Model for the ECB, August 2009

2761 Larry Karp, Sacrifice, Discounting and Climate Policy: Five Questions, August 2009

2762 Marianna Belloc and Samuel Bowles, International Trade, Factor Mobility and the Persistence of Cultural-Institutional Diversity, August 2009

2763 Charles Noussair and Fangfang Tan, Voting on Punishment Systems within a Heterogeneous Group, August 2009

2764 Birgit Bednar-Friedl and Karl Farmer, Internationally Coordinated Emission Permit Policies: An Option for Withdrawers from the Kyoto Protocol?, August 2009

2765 Pierre M. Picard and David E. Wildasin, Labor Market Pooling, Outsourcing and Labor Contracts, August 2009

2766 Stefan Voigt and Lorenz Blume, The Economic Effects of Federalism and Decentralization - A Cross-Country Assessment, August 2009

2767 David S. Jacks, Christopher M. Meissner and Dennis Novy, Trade Booms, Trade Busts, and Trade Costs, August 2009

2768 Mario Jametti and Thomas von Ungern-Sternberg, Hurricane Insurance in Florida, August 2009

2769 Alessandro Balestrino, Kind of Black: The Musicians' Labour Market in Italy, August 2009

2770 Yosr Abid Fourati and Cathal O’Donoghue, Eliciting Individual Preferences for Pension Reform, August 2009

2771 Christian Breuer and Chang Woon Nam, VAT on Intra-Community Trade and Bilateral Micro Revenue Clearing in the EU, August 2009

2772 Choudhry Tanveer Shehzad, Jakob De Haan and Bert Scholtens, Growth and Earnings Persistence in Banking Firms: A Dynamic Panel Investigation, August 2009

2773 Erdal Yalcin, Uncertain Productivity Growth and the Choice between FDI and Export, August 2009

2774 Klaus Abberger, Wolfgang Nierhaus and Shynar Shaikh, Findings of the Signal Approach for Financial Monitoring in Kazakhstan, September 2009 